\title{
Reduction of Net Sulfide Production Rate by Nitrate in Wastewater Bioreactors. Kinetics and Changes in the Microbial Community
}

\author{
D. Villahermosa • A. Corzo • J. M. González • \\ M. C. Portillo • E. García-Robledo • S. Papaspyrou
}

Received: 8 May 2013 / Accepted: 30 August 2013

(C) Springer Science+Business Media Dordrecht 2013

\begin{abstract}
Nitrate addition stimulated sulfide oxidation by increasing the activity of nitrate-reducing sulfide-oxidizing bacteria (NR-SOB), decreasing the concentration of dissolved $\mathrm{H}_{2} \mathrm{~S}$ in the water phase and, consequently, its release to the atmosphere of a pilot-scale anaerobic bioreactor. The effect of four different concentrations of nitrate $(0.12,0.24,0.50$, and $1.00 \mathrm{mM})$ was investigated for a period of 3 days in relation to sulfide concentration in two bioreactors set up at Guadalete wastewater treatment plant (Jerez de la Frontera, Spain). Physicochemical variables
\end{abstract}

D. Villahermosa $\cdot$ A. Corzo $\cdot$ E. García-Robledo Departamento de Biología, Facultad de Ciencias del Mar y Ambientales, Universidad de Cádiz,

Pol. Río San Pedro s/n, 11510 Puerto Real, Cádiz, Spain

J. M. González • M. C. Portillo

Instituto de Recursos Naturales y Agrobiología,

IRNAS-CSIC,

Avda. Reina Mercedes 10, 41012 Sevilla, Spain

\section{S. Papaspyrou}

Unidad asociada de Oceanografía Interdisciplinar, Instituto de Ciencias Marinas de Andalucía, ICMAN-CSIC, Pol. Río San Pedro s/n, 11510 Puerto Real, Cádiz, Spain

D. Villahermosa $(\triangle)$

Departamento de Biología, Facultad de Ciencias

del Mar y Ambientales,

Av. República Saharaui s/n, 11510 Puerto Real, Cádiz, Spain

e-mail: desiree.villahermosa@uca.es

Present Address:

S. Papaspyrou

Departamento de Biología, Facultad de Ciencias del Mar y

Ambientales, Universidad de Cádiz,

Pol. Río San Pedro s/n, 11510 Puerto Real, Cádiz, Spain were measured in water and air, and the activity of bacteria implicated in the sulfur and nitrogen cycles was analyzed in the biofilms and in the water phase of the bioreactors. Biofilms were a net source of sulfide for the water and gas phases $\left(7.22 \pm 5.3 \mu \mathrm{mol} \mathrm{s}^{-1}\right)$ in the absence of nitrate dosing. Addition of nitrate resulted in a quick (within $3 \mathrm{~h}$ ) decrease of sulfide both in the water and atmospheric phases. Sulfide elimination efficiency in the water phase increased with nitrate concentrations following the Michaelis-Menten kinetics $\left(K_{\mathrm{s}}=0.63 \mathrm{mM} \mathrm{NO}_{3}{ }^{-}\right)$. The end of nitrate addition resulted in a recovery or increase of initial net sulfide production in about $3 \mathrm{~h}$. Addition of nitrate increased the activity of NR-SOB and decreased the activity of sulfate-reducing bacteria. Results confirmed the role of NR-SOB on hydrogen sulfide consumption coupled with nitrate reduction and sulfate recycling, revealing Sulfurimonas denitrificans and Paracoccus denitrificans as NR-SOB of great importance in this process.

Keywords Sulfide removal · Autotrophic nitrate reduction $\cdot$ Wastewater $\cdot$ Biofilm $\cdot$ Kinetics $\cdot$ Microbial community

\section{Introduction}

Sulfate-reducing bacteria (SRB) are present in a wide range of environments from marine sediments to sewage systems. In anoxic conditions, they oxidize organic matter with sulfate as final electron acceptor producing hydrogen sulfide, which is toxic and corrosive, damages 
industrial facilities including wastewater treatment plants (WWTPs), and reduces the efficiency of the treatment process (Boon 1995; Beech and Sunner 2004).

Different physicochemical and biological methods have been proposed to control the negative effects of sulfide production in sewage environments and WWTP (Garcia de Lomas et al. 2006). Among the biological methods, addition of nitrate is considered one of the most suitable to control sulfide production (Jiang et al. 2009; Mohanakrishnan et al. 2009). However, different mechanisms have been suggested via which nitrate might reduce sulfide concentration: (1) by increasing the redox potential (Allen et al. 1949; Poduska and Anderson 1981), (2) by increasing pH (Aelion et al. 2000), (3) by inhibiting SRB (Yuan et al. 2010; Eckford and Fedorak 2004; Jenneman et al. 1986), (4) by causing a competition of SRB with heterotrophic nitrate-reducing bacteria for organic electron donors (Hubert and Voordouw 2007), (5) by the preferential use of nitrate as electron acceptor instead of sulfate by some species of SRB (Tang et al. 2009), or (6) by stimulating sulfide oxidation by nitrate-reducing sulfide-oxidizing bacteria (NR-SOB) (Mohanakrishnan et al. 2009; Garcia de Lomas et al. 2007; Vaiopoulou et al. 2005). Some of these mechanisms are not mutually exclusive, and their relative importance might change depending on environmental conditions. Previous studies demonstrated the implication of NR-SOB in the control of sulfide production in wastewater systems but did not exclude other alternatives (Garcia de Lomas et al. 2006, 2007).

Sulfide-oxidizing bacteria form a very heterogeneous group, with a high phylogenetic diversity, capable of using different reduced sulfur compounds $\left(\mathrm{H}_{2} \mathrm{~S}, \mathrm{~S}^{0}, \mathrm{~S}_{2} \mathrm{O}_{3}{ }^{2-}\right)$ as energy source (Roberts et al. 2000). Some are autotrophs and others use organic matter as carbon source. Most of them use oxygen as final electron acceptor, but in the absence of oxygen, some, the NR-SOB, are able to use $\mathrm{NO}_{3}{ }^{-}$as terminal electron acceptor and $\mathrm{H}_{2} \mathrm{~S}$ as source of electrons according to the following general equation:

$\mathrm{H}_{2} \mathrm{~S}+\mathrm{NO}_{3}{ }^{-} \rightarrow \mathrm{SO}_{4}{ }^{2-}+\mathrm{N}_{2}$

However, this reaction might occur through a number of intermediate reactions leading to different stoichiometries and the accumulation of $\mathrm{S}^{0}$ and $\mathrm{NO}_{2}{ }^{-}$or $\mathrm{N}_{2} \mathrm{O}$ in the external medium depending on the environmental conditions (Gadekar et al. 2006; Cardoso et al. 2006; Van Rijn et al. 2006; Nemati et al. 2001b). The production of $\mathrm{N}_{2}$ and other $\mathrm{N}$ gases like $\mathrm{N}_{2} \mathrm{O}$ and $\mathrm{NO}$ decreases the load of total nitrogen in the water phase. NR-SOB are widely spread in the Proteobacteria, having members from Alphaproteobacteria, Betaproteobacteria, Epsilonproteobacteria, and Gammaproteobacteria. In wastewaters, using RNA-based molecular methods, an increase of metabolic activity of several NR-SOB strains like Sulfurimonas denitrificans, Thiomicrospira sp., Arcobacter sp., and Thiobacillus denitrificans, associated to a decrease of sulfide in the presence of nitrate, both in mesoscale experimental bioreactors and in plant-scale experiments was observed (Garcia de Lomas et al. 2006, 2007). Similar strains are involved in the $\mathrm{NO}_{3}{ }^{-}$-dependent elimination of sulfide in oil reservoirs (Jenneman et al. 1986; Voordouw and Voordouw 1998; Nemati et al. 2001a). In fact, most current knowledge on the syntrophic relationship between SRB and NR-SOB has been obtained from a few strains isolated from the petroleum industry (Nemati et al. 2001a; Gevertz et al. 2000; Greene et al. 2003).

The addition of any chemical like nitrate to a WWTP is economically costly; therefore, it is highly convenient to find the minimum effective nitrate concentration needed to keep the sulfide concentration in the water phase as low as possible, avoiding its release to the atmosphere. Typically, the physicochemical characteristics of the inflow wastewater are highly variable even for a single WWTP; therefore, it is important to ensure that the addition of nitrate to reduce net sulfide production is a robust enough method for generalized application. The reduction of nitrate dose, and its cost for a given WWTP or sewage system, would likely encourage the application of this environmental technology in the wastewater treatment industry. In addition, so far, most studies dealing with the kinetic aspects and metabolism of NR-SOB have been done in small-scale cultures and bioreactors in wellcontrolled laboratory conditions and with specific NRSOB strains isolated from the oil industry (Gadekar et al. 2006; Gevertz et al. 2000; Hubert et al. 2009). On the contrary, we present here the response of an indigenous wastewater community to the addition of different doses of nitrate in two mesoscale bioreactors continuously fed with wastewater. The specific aims of our research were (1) to study the kinetics of sulfide disappearance and reappearance in the water and atmospheric 
phases after nitrate addition and suppression, (2) to confirm the stimulation of indigenous NR-SOB after nitrate addition through molecular biology techniques, and (3) to determine the dose-response curve of nitrate addition versus net sulfide production at a pilot scale using real wastewater.

\section{Materials and Methods}

\subsection{Bioreactors Setup and Working Conditions}

Two experimental bioreactors (fiberglass tanks, $175 \mathrm{~L}$ net volume) were set up at Guadalete WWTP (Jerez de la Frontera, Spain). Inflow wastewater was continuously collected from the WWTP after sand and oil removal with a conventional submerged water pump and passed through a sedimentation tank $(100 \mathrm{~L})$ to a distribution tank (100 L). Two membrane pumps (GA90P6P3, Dosapro Milton Roy) fed the bioreactors from the distribution tank at a constant flow rate (mean hydraulic retention time, $3.46 \mathrm{~h}$ ). The bioreactors were uniformly mixed with a rotor (K200-K90-T4, Kelvin) connected to a variable speed motor drive (SL205S, AC Tech $\left.^{\circledR}\right)$ set at $5 \mathrm{rpm}$. Each bioreactor was placed inside a plastic garden hut $\left(148 \times 81 \times 203 \mathrm{~cm}, 2.43 \mathrm{~m}^{3}\right)$ maintained closed and in darkness to preserve their own atmosphere and avoid sulfide photooxidation and photosynthesis. The bioreactors did not receive any specific microbial inoculum other than the continuous flow of wastewater. The setup was maintained under controlled conditions during 2 months to enable autochthonous biofilm to develop before the beginning of the experiments. Biofilms covered all submerged surfaces in both bioreactors including four nylon trays with a stainless steel coupon attached to the bioreactors' inner walls to increase the growth surface for biofilms and facilitate their samplings (Fig. 1).

During every experiment, a different stock solution of calcium nitrate $\left(\right.$ Nutriox $\left.^{\circledR}\right)$ was continuously supplied to one bioreactor (NBR) using a membrane pump (LANGEMP KKS, Henkel) for a period of 3 days, obtaining for each experiment a different final concentration: 0.12, $0.24,0.50$, or $1.00 \mathrm{mM} \mathrm{NO}_{3}{ }^{-}$. The other reactor was used as a control (CBR). Chemical and biological variables were monitored in both bioreactors before, during, and after nitrate dosage in each experiment (5-8 days). Between experiments, both bioreactors operated at a minimum of 1 month without nitrate addition in order

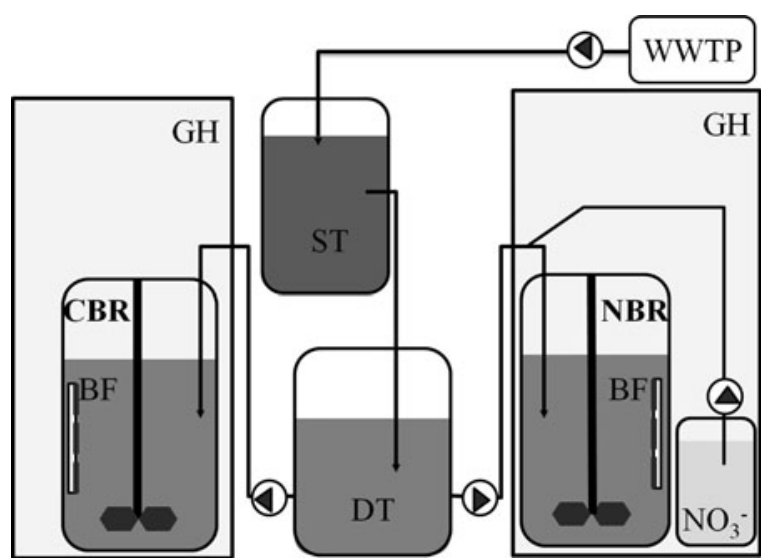

Fig. 1 Experimental setup. Sedimentation tank $(S T)$, distribution tank $(D T)$, control bioreactor $(C B R)$, nitrate bioreactor $(N B R)$, garden huts $(G H)$, and trays for biofilm growth $(B F)$

to reestablish initial conditions. The four experiments were done at different dates during 2009.

\subsection{Chemical Variables}

Water samples were filtered in situ with $47 \mathrm{~mm}$ precombusted GF/F (nominal pore, $0.7 \mu \mathrm{m}$ ) Whatman filters for $\mathrm{NO}_{3}{ }^{-}, \mathrm{NO}_{2}{ }^{-}, \mathrm{NH}_{4}^{+}$, and dissolved organic carbon (DOC) samples, transported refrigerated to the laboratory $(0.5$ to $12 \mathrm{~h}$ ), and kept frozen until analysis. $\mathrm{NO}_{2}{ }^{-}$and $\mathrm{NH}_{4}{ }^{+}$concentrations were determined photometrically (PowerWave 340 Microplate Spectrophotometer, Bio-Tek ${ }^{\circledR}$ ) after the method of Grasshoff et al. (1983). $\mathrm{NO}_{3}{ }^{-}+\mathrm{NO}_{2}{ }^{-}$concentrations were determined photometrically after the method of Zhang and Fischer (2006), and $\mathrm{NO}_{3}{ }^{-}$was determined by subtracting $\mathrm{NO}_{2}{ }^{-}$ concentration. DOC samples were preserved with two drops of concentrated sulfuric acid and analyzed by combustion and infrared detection (TOC-5000A). Sulfate concentration was measured by turbidimetry (American Public Health Association, American Water Works Association, and Water Environment Federation 2005). Sulfide samples were taken in $1.5 \mathrm{ml}$ Eppendorf ${ }^{\circledR}$ vials and preserved with a drop of $0.22 \mathrm{~g} \mathrm{~mL}^{-1}$ zinc acetate immediately after filtration, refrigerated until reaching the laboratory, and frozen until determined colorimetrically after the method of Cord-Ruwisch (1985). Atmospheric $\mathrm{H}_{2} \mathrm{~S}$ in the garden huts produced by each bioreactor was monitored continuously with two Data Logger OdaLog (App-Tek International Pty Ltd.). Weekly, the physicochemical properties of the raw wastewater entering the Guadalete WWTP were monitored. Water samples were 
collected before grit removal every 15 min during 1 day and pooled with a portable Sample Taker (Sigma SD900, $\mathrm{HACH})$.

The steady-state net production (positive values) and consumption (negative values) rates of bioreactors were calculated according to the following equation:

Net production rates $=((B R-D T) V B R / S B R) / H R T$

where $\mathrm{BR}$ is the mean concentration of the compound at 24,48 , and $72 \mathrm{~h}$ after nitrate addition in CBR or NBR; DT is the mean steady-state concentration in the distribution tank; VBR is the bioreactor volume $(175 \mathrm{~L})$; SBR is the internal surface of each bioreactor $\left(1.26 \mathrm{~m}^{2}\right)$; and HRT is the hydraulic retention time.

The sulfide elimination efficiency (SEE) in the water phase was defined as:

$S E E=\left[\mathrm{H}_{2} \mathrm{~S}_{C B R}-\mathrm{H}_{2} \mathrm{~S}_{N B R}\right] / \mathrm{H}_{2} \mathrm{~S}_{C B R}$

where $\mathrm{H}_{2} \mathrm{~S}_{\mathrm{CBR}}$ and $\mathrm{H}_{2} \mathrm{~S}_{\mathrm{NBR}}$ are the concentrations of sulfide measured in CBR and NBR from $24 \mathrm{~h}$ after the start of nitrate addition until the end of nitrate addition.

\subsection{Analysis of Microbial Community Composition}

Samples for RNA analysis were taken $72 \mathrm{~h}$ after starting nitrate addition from the biofilms growing on the metal coupons, representing the "steady-state" active microbial communities under different nitrate dosages. Samples were preserved in situ with RNAlater ${ }^{\circledR}$ (Ambion, Inc., Austin, TX, USA) (10× volume) and preserved at $-80{ }^{\circ} \mathrm{C}$ in the laboratory. Microbial communities were analyzed by quantitative, real-time reverse transcription polymerase chain reaction (PCR). RNA was extracted from CBR and NBR samples using the RNAqueous4PCR total RNA extraction kit (Ambion, Inc.). Reverse transcription was performed using ThermoScript (Invitrogen, Carlsbad, CA, USA) as previously described (Garcia de Lomas et al. 2006). Quantitative PCRs were carried out using the iQ SYBR Green Supermix for realtime PCR (Bio-Rad, Hercules, CA, USA). Triplicate reactions were processed under the following cycling conditions: $95^{\circ} \mathrm{C}$ for $5 \mathrm{~min}$ and 40 cycles of $95^{\circ} \mathrm{C}$ for $15 \mathrm{~s}$, $62{ }^{\circ} \mathrm{C}$ for $15 \mathrm{~s}$, and $72{ }^{\circ} \mathrm{C}$ for $45 \mathrm{~min}$. Fluorescence produced from SYBR Green was determined at the end of the extension step. Based on preliminary information, 16S ribosomal RNA (rRNA) genes belonging to selected groups of SRB and NR-SOB were targeted in the quantitative amplification experiments, as an indicator of bacterial metabolic activity (Molin and Givskov 1999). All quantifications were normalized according to the total bacterial 16S rRNA genes. We report the relative abundances of 16S rRNA genes in the total RNAs extracted from the nitrate-supplemented and unsupplemented treatments. Quantitative PCR estimates were performed according to the sigmoidal nonlinear curve-fitting procedure previously proposed by Rutledge (2004). SRB in the studied wastewater were represented by the five most abundant phylogenetic branching groups of SRB (sensu Daly et al. 2000). Among the NR-SOB, according to previous studies in this system, three major participating bacterial groups were studied, represented by $S$. denitrificans, T. denitrificans, and Paracoccus denitrificans. The primers used for the quantitative amplification of these bacterial groups are listed in Table 1.

\subsection{Statistical Analysis}

Differences in the means in different years of chemical variable concentrations in the WWTP were calculated using the Mann-Whitney rank sum test with Sigma Plot 11.0 (Systat Software, Inc. SigmaPlot for Windows). Statistical significance was evaluated by $t$ test or paired $t$ test, Shapiro-Wilk normality test, and Wilcoxon test (when normality test was not passed) using Sigma Plot 11.0 (Systat Software, Inc. SigmaPlot for Windows).

\section{Results}

3.1 Variability of Chemical Variables in the Wastewater Treatment Plant

The physicochemical characteristics of the wastewater inflow in the Guadalete WWTP were largely variable during the time at which the experiments were carried out (Table 2). Moreover, this high variability in the physicochemical characteristic of wastewater during 2009 is typical of Guadalete WWTP as it is evident when comparing 2008 and 2009 data. Interannual differences were significant for some variables (sulfate, ammonium, biochemical oxygen demand [BOD], chemical oxygen demand [COD], and $\mathrm{pH}$ ) and not significant for sulfide, nitrate, or nitrite $(p>0.001$, Mann-Whitney rank sum test). 
Table 1 Primers used for the quantitative amplification of specific bacterial groups

\begin{tabular}{|c|c|c|c|}
\hline Target bacterial group & Primer name & Primer sequence $\left(5^{\prime} \rightarrow 3^{\prime}\right)$ & Reference \\
\hline Bacteria & $\begin{array}{l}27 \mathrm{~F} \\
518 \mathrm{R}\end{array}$ & $\begin{array}{l}\text { AGA GTT TGA TYM TGG CTC AG } \\
\text { ATT ACC GCG GCT GCT GG }\end{array}$ & $\begin{array}{l}\text { Snaidr et al. } 1997 \\
\text { Neefs et al. } 1990\end{array}$ \\
\hline \multicolumn{4}{|l|}{ SRB } \\
\hline Desulfobulbus & $\begin{array}{l}\text { DBB121 } \\
\text { DBB1237 }\end{array}$ & $\begin{array}{l}\text { CGC GTA GAT AAC CTG TCY TCA TG } \\
\text { GTA GKA CGT GTG TAG CCC TGG TC }\end{array}$ & $\begin{array}{l}\text { Daly et al. (2000) } \\
\text { Daly et al. (2000) }\end{array}$ \\
\hline Desulfobacterium & $\begin{array}{l}\text { DBM169 } \\
\text { DBM1006 }\end{array}$ & $\begin{array}{l}\text { CTA ATR CCG GAT RAA GTC AG } \\
\text { ATT CTC ARG ATG TCA AGT CTG }\end{array}$ & $\begin{array}{l}\text { Daly et al. (2000) } \\
\text { Daly et al. (2000) }\end{array}$ \\
\hline Desulfobacter & $\begin{array}{l}\text { DSB127 } \\
\text { DSB1273 }\end{array}$ & $\begin{array}{l}\text { GAT AAT CTG CCT TCA AGC CTG G } \\
\text { CYY YYY GCR RAG TCG STG CCC T }\end{array}$ & $\begin{array}{l}\text { Daly et al. (2000) } \\
\text { Daly et al. (2000) }\end{array}$ \\
\hline $\begin{array}{l}\text { Desulfococcus, Desulfonema, } \\
\text { Desulfosarcina }\end{array}$ & $\begin{array}{l}\text { DCC } 305 \\
\text { DCC } 1165\end{array}$ & $\begin{array}{l}\text { GAT CAG CCA CAC TGG RAC TGA CA } \\
\text { GGG GCA GTA TCT TYA GAG TYC }\end{array}$ & $\begin{array}{l}\text { Daly et al. (2000) } \\
\text { Daly et al. (2000) }\end{array}$ \\
\hline Desulfovibrio, Desulfomicrobium & $\begin{array}{l}\text { DSV230 } \\
\text { DSV838 }\end{array}$ & $\begin{array}{l}\text { GRG YCY GCG TYY CAT TAG C } \\
\text { SYC CGR CAY CTA GYR TYC ATC }\end{array}$ & $\begin{array}{l}\text { Daly et al. (2000) } \\
\text { Daly et al. (2000) }\end{array}$ \\
\hline \multicolumn{4}{|l|}{ NR-SOB } \\
\hline Paracoccus denitrificans & $\begin{array}{l}\text { Pd90F } \\
\text { Pd572R }\end{array}$ & $\begin{array}{l}\text { CGG AAT AGY CCY GGG AAA CTG GG } \\
\text { CTC TCT CGA ACT CCA GAC CGA }\end{array}$ & $\begin{array}{l}\text { This study } \\
\text { This study }\end{array}$ \\
\hline Sulfurimonas denitrificans & $\begin{array}{l}\text { TM277F } \\
\text { TM455R }\end{array}$ & $\begin{array}{l}\text { GCT TTG RGA TCA GAC TAT ATC C } \\
\text { CAC CGA AAT GCG TCA TCC TC }\end{array}$ & $\begin{array}{l}\text { Garcia de Lomas et al. (2006) } \\
\text { Garcia de Lomas et al. (2006) }\end{array}$ \\
\hline Thiobacillus denitrificans & $\begin{array}{l}\text { TB730F } \\
\text { TB940R }\end{array}$ & $\begin{array}{l}\text { ACT GGY AGT CTA GAG TGC GTC } \\
\text { TCG TTA CTA AGG GAT TTC ACT }\end{array}$ & $\begin{array}{l}\text { Garcia de Lomas et al. (2006) } \\
\text { Garcia de Lomas et al. (2006) }\end{array}$ \\
\hline
\end{tabular}

Ammonium represented the main source of inorganic nitrogen in the raw wastewater. The average ammonium inflow in the plant during 2008-2009 was $2.30 \pm 1.16 \mathrm{mM}$, whereas the nitrate mean concentration in the inflow water was one order of magnitude lower $(204 \pm 596 \mu \mathrm{M})$. Nitrite mean concentration was two orders of magnitude lower than nitrate $\left(8 \pm 10 \mu \mathrm{M} \mathrm{NO}_{2}{ }^{-}\right)$; however, maximum nitrate peaks of 5.8 and $1.3 \mathrm{mM}$ were measured during 2008 and 2009 , respectively. Sulfate and sulfide concentrations in the raw wastewater were similarly variable, with mean values of $2.8 \pm 0.8 \mathrm{mM}$ and $7.0 \pm 7.7 \mu \mathrm{M}$, respectively.

3.2 Effect of Nitrate Addition on Net Sulfide Production in the Water Phase

Average sulfide concentration in the distribution tank was relatively low and variable during the experiments $\left(0.12 \pm 0.12 \mathrm{mM} \mathrm{H}_{2} \mathrm{~S}\right)$ but higher than in the inflow water

Table 2 Mean \pm standard deviation and maximum and minimum values in parentheses of chemicals measured from the raw wastewater of the WWTP feeding the bioreactors ( $n=365$ for 2008 and $n=363$ for 2009 for $\mathrm{DBO}_{5}$, DQO, and pH, the rest $n=52$ )

\begin{tabular}{lll}
\hline & 2008 mean \pm SD (range) & 2009 mean \pm SD (range) \\
\hline $\mathrm{SO}_{4}{ }^{2-}(\mathrm{mM})^{\mathrm{a}}$ & $3.20 \pm 0.87(1.51-6.99)$ & $2.42 \pm 0.46(1.51-4.00)$ \\
$\mathrm{H}_{2} \mathrm{~S}(\mu \mathrm{M})$ & $6.67 \pm 4.21(0.89-24.09)$ & $7.46 \pm 10.38(0.31-66.51)$ \\
$\mathrm{NH}_{4}{ }^{-}(\mathrm{mM})^{\mathrm{a}}$ & $2.34 \pm 0.76(0.44-3.75)$ & $2.25 \pm 1.50(0.69-11.42)$ \\
$\mathrm{NO}_{2}{ }^{-}(\mu \mathrm{M})$ & $7.01 \pm 8.45(0.63-55.00)$ & $9.03 \pm 12.08(1.20-62.40)$ \\
$\mathrm{NO}_{3}{ }^{-}(\mu \mathrm{M})$ & $216.42 \pm 797.87(35.50-5,822.10)$ & $191.36 \pm 225.52(13.00-1,304.70)$ \\
$\left.\mathrm{BOD}_{5}(\mathrm{mg} \mathrm{L})^{-1}\right)^{\mathrm{a}}$ & $359 \pm 106(80-780)$ & $269 \pm 85(40-680)$ \\
$\left.\mathrm{COD}^{-(m g ~ L}\right)^{\mathrm{a}}$ & $572 \pm 153(148-1,350)$ & $452 \pm 167(78-952)$ \\
$\mathrm{pH}^{\mathrm{a}}$ & $7.42 \pm 0.17(6.86-8.16)$ & $7.50 \pm 0.16(6.87-7.98)$ \\
\hline
\end{tabular}

\footnotetext{
${ }^{\mathrm{a}}$ The comparison between means of both years is significantly different ( $p<0.001$, Mann-Whitney rank sum test)
} 
Fig. 2 Evolution of $\mathrm{H}_{2} \mathrm{~S}$ concentration in the water phase (mean $\pm \mathrm{SD}, n=3)$ of the distribution tank (dashed line), CBR (empty circle), and NBR (black circle). Nitrate was added at time 0 . Dashed vertical line shows the end of nitrate addition
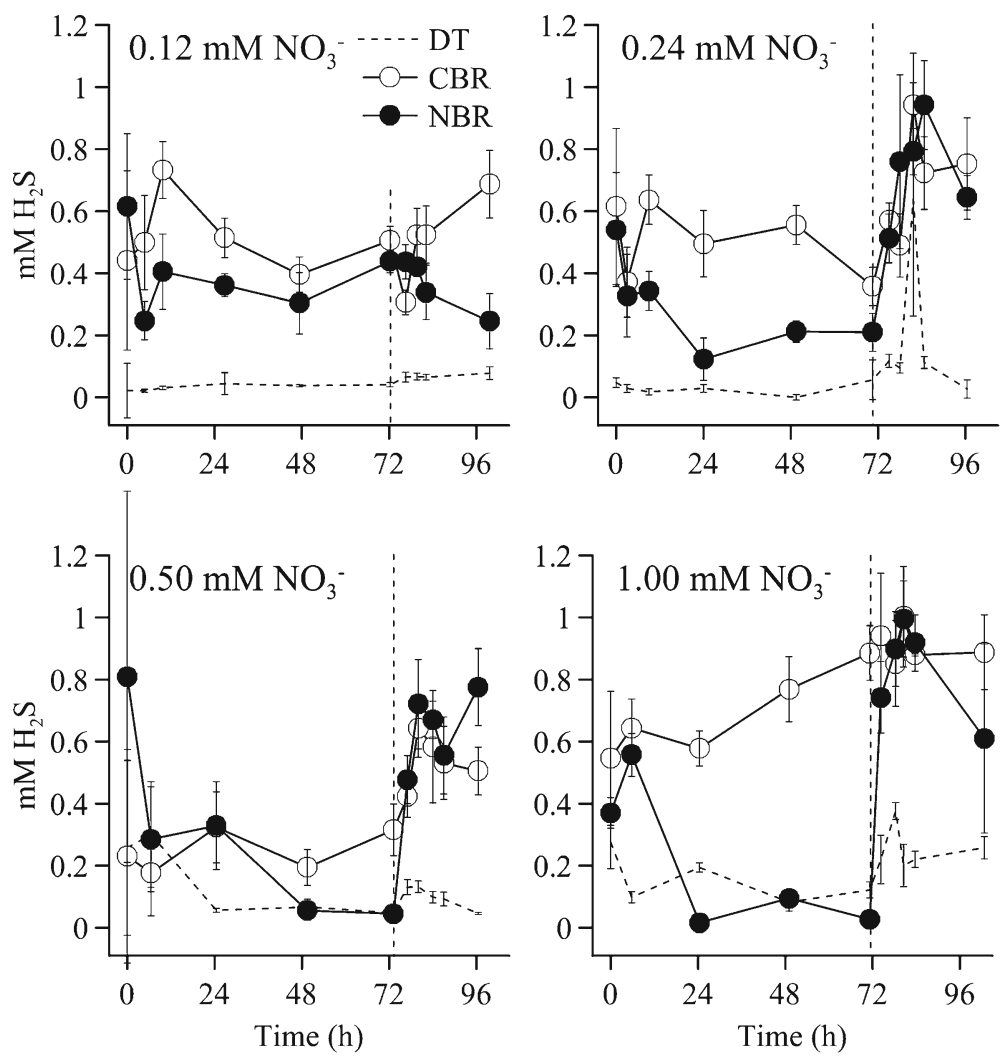

and lower than in the bioreactors without nitrate addition (Fig. 2). Thus, both bioreactors acted as net sulfide producers in the absence of nitrate addition ( $p<0.01, t$ test). The mean net sulfide production in the control bioreactors during the experiments was $17.86 \pm 9.34 \mathrm{mmol}$ $\mathrm{H}_{2} \mathrm{~S} \mathrm{~m}^{-2} \mathrm{~h}^{-1}$.

During nitrate addition, the steady-state net sulfide production rates $(24-72 \mathrm{~h}$ after initiation of nitrate addition) were always lower in NBR than in CBR and decreased linearly with $\mathrm{NO}_{3}{ }^{-}$addition at a mean rate of $14 \mathrm{mmol} \mathrm{H}_{2} \mathrm{~S} \mathrm{~m}^{-2} \mathrm{~h}^{-1}$ per millimolar of $\mathrm{NO}_{3}{ }^{-}$ added (Table 3 ). This resulted in a maximal reduction of $94 \%$ at $1 \mathrm{mM}$ nitrate with respect to CBR (Fig. 2).

In order to compare the effect of the nitrate concentrations and to account for the inherent variability in the bioreactors, sulfide concentration was normalized in two ways: (1) by the concentration of sulfide in CBR in each experiment and (2) by the initial sulfide concentration in NBR before addition of nitrate. Both approaches resulted in a similar trend, an exponential sulfide decrease with increasing nitrate concentrations, with only about $10 \%$ of initial sulfide remaining in the water phase when nitrate dosage to NBR was $1 \mathrm{mM}$ (Fig. 3).
The SEE (Eq. 3) was dependent on the added nitrate concentration in a saturating way (Fig. 4), showing a statistically significant fit to a Michaelis-Menten kinetic with $K_{\mathrm{s}}$ of $0.63 \mathrm{mM}(p<0.05)$.

The effect of nitrate was quickly reversible. Sulfide concentration immediately increased when nitrate addition ceased (Fig. 2). Sulfide values, normalized with the concentration of $\mathrm{H}_{2} \mathrm{~S}$ at the cessation of nitrate addition, increased 4-fold for 0.24 and $0.50 \mathrm{mM}$ and 20-fold for $1 \mathrm{mM}$ nitrate addition, following a hyperbolic relationship with time (Fig. 5). The recovery of sulfide was quick, reaching half of the final concentration in about $1 \mathrm{~h}$ $(1.04 \pm 0.59 \mathrm{~h})$.

\subsection{Effect of Nitrate Dosage on the Release of Sulfide to the Atmospheric Phase}

The concentration of sulfide in the huts' atmospheres was highly variable with time and among experiments, with a range of 0 to $16.5 \mathrm{ppm}$ and a mean of $1.96 \pm 1.95 \mathrm{ppm}$ (data from January 2009 to September 2009, CBR hut, $n=8,179$ ). Because sulfide was continuously monitored, the opening of the hut door for sampling and service was 
Table 3 Steady-state net production (positive values) or consumption rates (negative values) of several N, S, and C compounds (in millimoles per square meter per hour and in grams per square meter per hour only for DOC)

\begin{tabular}{|c|c|c|c|c|c|c|}
\hline \multirow[t]{2}{*}{ Tank } & \multirow[t]{2}{*}{ Variable } & \multicolumn{4}{|c|}{ Nitrate concentration added (mM) } & \multirow[t]{2}{*}{ Mean } \\
\hline & & 0.12 & 0.24 & 0.50 & 1.00 & \\
\hline \multirow[t]{7}{*}{ CBR } & $\mathrm{NO}_{3}^{-}$ & $-0.04 \pm 0.13$ & $-0.10 \pm 0.19$ & $0.01 \pm 0.05$ & $-1.17 \pm 1.82$ & $-0.32 \pm 0.93^{*}$ \\
\hline & $\mathrm{NO}_{2}^{-}$ & $0.04 \pm 0.11$ & $-0.01 \pm 0.11$ & $0.02 \pm 0.01$ & $-0.02 \pm 0.16$ & $0.01 \pm 0.10^{*}$ \\
\hline & $\mathrm{NH}_{4}^{+}$ & $0.60 \pm 20.27$ & $5.84 \pm 32.00$ & $9.69 \pm 8.14$ & $40.27 \pm 32.90$ & $14.10 \pm 27.02$ \\
\hline & $\mathrm{TIN}^{\mathrm{a}}$ & 0.60 & 5.73 & 9.72 & 39.09 & 13.79 \\
\hline & $\mathrm{H}_{2} \mathrm{~S}$ & $13.64 \pm 2.00$ & $15.14 \pm 4.43$ & $11.03 \pm 4.04$ & $31.65 \pm 10.40$ & $17.86 \pm 9.92 *$ \\
\hline & $\mathrm{SO}_{4}^{2-}$ & $-25.51 \pm 22.55$ & $-26.79 \pm 8.64$ & $-10.04 \pm 11.84$ & $-22.90 \pm 17.09$ & $-21.31 \pm 15.26$ \\
\hline & DOC & $0.39 \pm 0.49$ & $0.11 \pm 0.4$ & $0.01 \pm 0.22$ & $0.22 \pm 0.14$ & $0.18 \pm 0.33^{*}$ \\
\hline \multirow[t]{7}{*}{ NBR } & $\mathrm{NO}_{3}^{-}$ & $-3.89 \pm 0.12$ & $-8.28 \pm 0.2$ & $-25.02 \pm 0.23$ & $-52.92 \pm 1.67$ & $-22.53 \pm 20.11 *$ \\
\hline & $\mathrm{NO}_{2}^{-}$ & $0.05 \pm 0.08$ & $-0.00 \pm 0.08$ & $0.22 \pm 0.14$ & $0.18 \pm 0.33$ & $0.11 \pm 0.19^{*}$ \\
\hline & $\mathrm{NH}_{4}^{+}$ & $-9.45 \pm 25.86$ & $-6.13 \pm 26.03$ & $23.15 \pm 12.53$ & $22.51 \pm 15.74$ & $7.52 \pm 23.99$ \\
\hline & TIN & -9.49 & -6.17 & 23.34 & 21.57 & 7.31 \\
\hline & $\mathrm{H}_{2} \mathrm{~S}$ & $10.35 \pm 2.10$ & $5.26 \pm 2.03$ & $4.30 \pm 8.07$ & $-4.49 \pm 4.93$ & $3.86 \pm 6.99^{*}$ \\
\hline & $\mathrm{SO}_{4}^{2-}$ & $-28.61 \pm 19.81$ & $-22.34 \pm 21.39$ & $-18.47 \pm 9.68$ & $-38.73 \pm 7.09$ & $-27.04 \pm 15.64$ \\
\hline & DOC & $0.32 \pm 0.41$ & $-0.12 \pm 0.12$ & $-0.23 \pm 0.17$ & $-0.12 \pm 0.12$ & $-0.04 \pm 0.30 *$ \\
\hline
\end{tabular}

${ }^{*} p<0.05$, statistically significant difference between NBR and CBR

${ }^{\mathrm{a}}$ Total inorganic nitrogen $\left(\mathrm{TIN}=\mathrm{NH}_{4}{ }^{+}+\mathrm{NO}_{3}{ }^{-}+\mathrm{NO}_{2}{ }^{-}\right.$)

registered as a sudden decrease of $\mathrm{H}_{2} \mathrm{~S}_{\text {atm }}$ (Fig. 6). Atmospheric sulfide concentration was linearly correlated with the concentration in the aqueous phase of bioreactors $\left(\mathrm{H}_{2} \mathrm{~S}_{\mathrm{atm}}=0.16 \times \mathrm{H}_{2} \mathrm{~S}_{\mathrm{aq}}, r=0.682, p<0.0001, n=154\right)$.

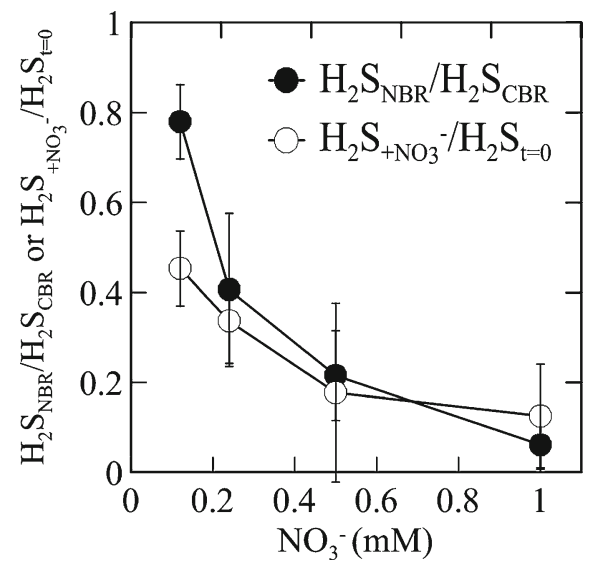

Fig. 3 Sulfide decrease in the water phase of NBR with nitrate. Ratio of sulfide concentration in NBR/CBR during nitrate addition (black circles) and ratio of sulfide concentration during nitrate addition divided into sulfide concentration at time 0 in NBR (white circles) with their standard deviations
Nitrate addition in NBR decreased sulfide emission to the atmosphere, which was also dependent on the nitrate concentration added (Fig. 6). With $0.12 \mathrm{mM}$ nitrate sulfide, emission decreased 33 and $45 \%$ with respect to the control and the initial conditions, respectively, and 73 and $81 \%$ with $0.24 \mathrm{mM} \mathrm{NO}_{3}{ }^{-}$. Only occasionally very low or

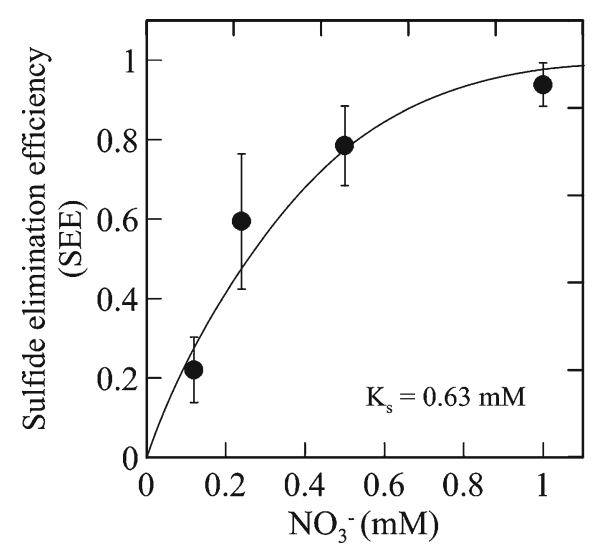

Fig. 4 SEE in the water phase at different nitrate concentrations. Experimental data were fitted to a Michaelis-Menten kinetics $(r=0.682, p<0.05)$ 


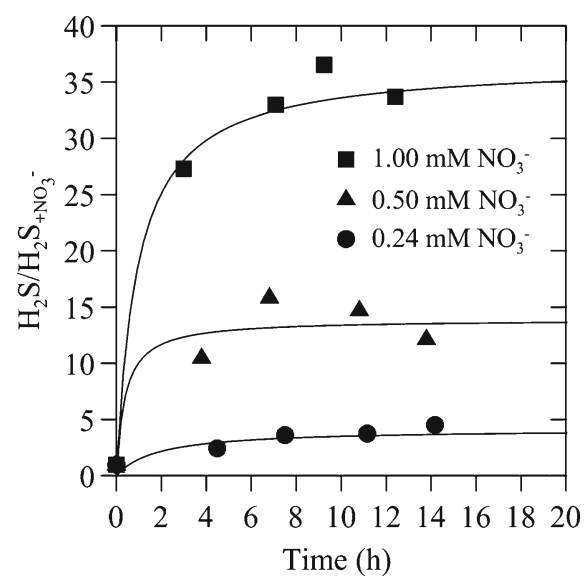

Fig. 5 Time course of the recovery of sulfide concentration in NBR. Sulfide concentration was normalized to the values before the end of nitrate addition. $R^{2}$ are $0.6459,0.7645$, and 0.6819 for the experiments at $0.24,0.50$, and $1.0 \mathrm{mM} \mathrm{NO}_{3}{ }^{-}$, respectively

even none at all was detected with 0.5 and $1 \mathrm{mM} \mathrm{NO}_{3}{ }^{-}$. Once nitrate dosage stopped, sulfide concentrations at the atmosphere recovered initial values.

\subsection{Nitrogen, Sulfur, and Carbon Mass Balance in the Presence and Absence of Added Nitrate}

Both bioreactors were net consumers of nitrate since the concentrations in their water phases were always significantly lower than in the distribution tank and in the inflow raw wastewater (Tables 2 and 4). The nitrate added to the NBR was quickly consumed by the microbial community (within $3 \mathrm{~h}$ ) since $\mathrm{NO}_{3}{ }^{-}$concentrations were not significantly different between NBR and CBR (paired $t$ test, $p=0.943$ ). Added nitrate did not accumulate as $\mathrm{NO}_{3}{ }^{-}$or $\mathrm{NH}_{4}{ }^{+}$(Table 4). However, a small accumulation of nitrite $(4 \mu \mathrm{M})$ was measured in NBR when nitrate addition was $0.50 \mathrm{mM}$ or higher (paired $t$ test, $p<0.05$ ).

We calculated the mean steady-state net production of relevant $\mathrm{N}, \mathrm{S}$, and $\mathrm{C}$ compounds during nitrate addition in each experiment (Table 3 ) to analyze the effect of nitrate addition on their dynamics and stoichiometry. Despite of the great variability between different experiments, several consistent trends were observed. In general, both CBR and NBR were net producers of $\mathrm{NH}_{4}{ }^{+}$ and net consumers of $\mathrm{SO}_{4}{ }^{2-}$ with different but not statistically significant rates. They were also net producers of $\mathrm{NO}_{2}{ }^{-}$and $\mathrm{H}_{2} \mathrm{~S}$; however, nitrite production was significantly higher in NBR than in CBR, while net $\mathrm{H}_{2} \mathrm{~S}$ production was higher in CBR than in NBR. The net production rate of DOC was positive in CBR, while it tended to be negative in NBR, being this difference statistically significant (Table 3 ).

\subsection{Changes in the Microbial Community}

The selected bacterial groups analyzed, including NRSOB species (S. denitrificans, P. denitrificans, and T. denitrificans) and the most abundant SRB genera (Desulfobulbus, Desulfobacterium, Desulfobacter, Desulfococcus, Desulfonema, Desulfosarcina, Desulfovibrio, and Desulfomicrobium), comprised up to $24 \%$ of total bacterial sequences. The active microbial community in CBR was dynamic, showing significant differences in the activity of SRB and NR-SOB species among the different experiments (Fig. 7). Nevertheless, the addition of nitrate to NBR induced clear changes in the activity of the microbial community, but not always in the same direction (Table 5; Fig. 7). The general pattern of changes in the microbial community after $72 \mathrm{~h}$ of adding nitrate was an increase of the sequences of NR-SOB (6.1-fold) and a decrease of SRB (1.5 times without the Desulfovibrio group). The highest differences in the activity of these microbial communities between NBR and CBR were found at the 0.24 and $0.50 \mathrm{mM} \mathrm{NO}_{3}^{-}$experiments (Table 5). S. denitrificans and P. denitrificans always increased their relative activity with the addition of nitrate with respect to the control. However, the increase was not similar in every experiment, with maxima increases detected with 0.24 and $0.50 \mathrm{mM} \mathrm{NO}_{3}{ }^{-}$. T. denitrificans increased in the 0.24 and $0.50 \mathrm{mM} \mathrm{NO}_{3}{ }^{-}$experiments and decreased in 0.12 and $1 \mathrm{mM} \mathrm{NO}_{3}^{-}$.

High increases in $S$. denitrificans and $P$. denitrificans, 21.5 and 27.8 times, respectively, were recorded in NBR with respect to $\mathrm{CBR}$ in the $0.24 \mathrm{mM} \mathrm{NO}_{3}{ }^{-}$enrichment, an order of magnitude larger than in the other experiments. Regarding the SRB community, we found in this experiment a general low response to nitrate addition with the exception of the Desulfovibrio-Desulfomicrobium group, which increased two orders of magnitude compared to the control (Table 5; Fig. 7).

\section{Discussion}

The addition of nitrate always induced a reduction of sulfide concentration despite that each experiment was performed at different dates during the year and started with different physicochemical conditions in the wastewater entering the system (Table 2). Physicochemical 
Fig. 6 Atmospheric $\mathrm{H}_{2} \mathrm{~S}$ concentrations in NBR (black line) and CBR (gray line) and temperature (dashed line) over time. White window corresponds with nitrate addition. Data smoothed with simple moving average of $30 \mathrm{~min}$
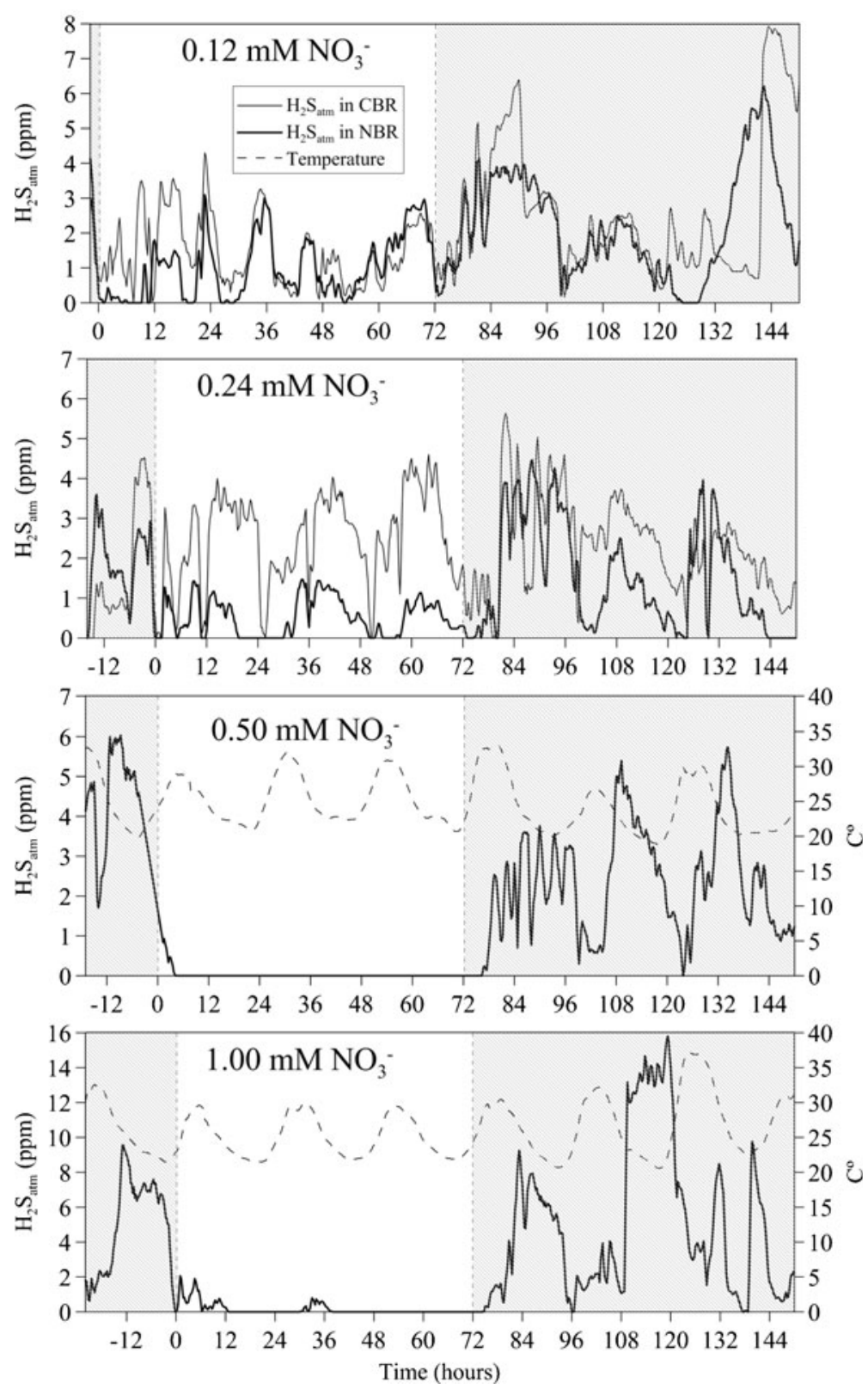

conditions in the wastewater are affected by unpredictable changes in climatic variables (e.g., precipitation, temperature) and seasonal changes in human uses and consumption of water (Leitao et al. 2006). Several key compounds involved in the microbial processes studied (related to SRB and NR-SOB) such as nitrate, sulfide, and sulfate varied even up to two orders of magnitude among the experiments. The amount of sulfide in the raw wastewater was variable but generally low (about $6 \mu \mathrm{M}$; Table 2), being much lower than in other studies (usually $>1 \mathrm{mM}$; see Table VI in Garcia de Lomas et al. 2006). Our experimental system was a net producer of sulfide, with the mean net production rate in the water phase of CBR being $17.86 \pm 9.34 \mathrm{mmol} \mathrm{m}^{-2} \mathrm{~h}^{-1}$ (Table 3), which is within the mean sulfide production calculated for a 200- $\mu \mathrm{m}$ biofilm (Nielsen 1987). Changes in the concentration of sulfate entering the reactors are important for the kinetics of the reaction and to determine the optimal nitrate dose since most of sulfide in the wastewater is being produced by SRB using sulfate as terminal electron acceptor. These differences in the input wastewater likely 
Table 4 Mean concentrations \pm standard deviation $(n=10-12)$ of different forms of inorganic $\mathrm{N}$ and $\mathrm{S}$ in the bioreactors for the whole duration of the experiments (5 to 8 days)

\begin{tabular}{|c|c|c|c|c|c|}
\hline \multirow[t]{2}{*}{ Tank } & \multirow[t]{2}{*}{ Variable } & \multicolumn{4}{|c|}{ Nitrate concentration added (mM) } \\
\hline & & $0.12^{\mathrm{a}}$ & $0.24^{\mathrm{b}}$ & $0.50^{\mathrm{b}}$ & $1.00^{\mathrm{c}}$ \\
\hline \multirow[t]{5}{*}{ CBR } & $\mathrm{NO}_{3}^{-}$ & $16.3 \pm 6.0$ & $16.6 \pm 3.9$ & $16.7 \pm 4.2$ & $15.9 \pm 4.0$ \\
\hline & $\mathrm{NO}_{2}^{-}$ & $5.1 \pm 1.9$ & $1.5 \pm 0.8$ & $1.0 \pm 0.3$ & $2.0 \pm 0.5$ \\
\hline & $\mathrm{NH}_{4}^{+}$ & $2.52 \pm 0.27$ & $3.43 \pm 0.98$ & $2.75 \pm 0.63$ & $2.67 \pm 0.27$ \\
\hline & $\mathrm{SO}_{4}{ }^{2-}$ & $2.43 \pm 0.27$ & $2.39 \pm 0.35$ & $2.06 \pm 0.21$ & $1.89 \pm 0.39$ \\
\hline & $\mathrm{H}_{2} \mathrm{~S}$ & $0.48 \pm 0.17$ & $0.59 \pm 0.09$ & $0.35 \pm 0.14$ & $0.88 \pm 0.42$ \\
\hline \multirow[t]{5}{*}{ NBR } & $\mathrm{NO}_{3}^{-}$ & $15.7 \pm 4.8$ & $17.8 \pm 3.2$ & $22.8 \pm 12.1$ & $25.7 \pm 16.8$ \\
\hline & $\mathrm{NO}_{2}^{-}$ & $5.1 \pm 1.1$ & $1.5 \pm 0.3$ & $7.8 \pm 8.8$ & $2.8 \pm 0.3$ \\
\hline & $\mathrm{NH}_{4}^{+}$ & $2.31 \pm 0.28$ & $3.23 \pm 0.66$ & $2.85 \pm 0.45$ & $2.64 \pm 0.48$ \\
\hline & $\mathrm{SO}_{4}{ }^{2-}$ & $2.34 \pm 0.19$ & $2.46 \pm 0.49$ & $2.02 \pm 0.31$ & $1.79 \pm 0.35$ \\
\hline & $\mathrm{H}_{2} \mathrm{~S}$ & $0.37 \pm 0.09$ & $0.44 \pm 0.24$ & $0.51 \pm 0.39$ & $0.62 \pm 0.43$ \\
\hline
\end{tabular}

Ammonia, sulfate, and sulfide concentrations in millimolars; nitrate and nitrite in micromolars

${ }^{\mathrm{a}} n=10$

${ }^{\mathrm{b}}{ }_{n=11}$

${ }^{\mathrm{c}}{ }_{n=12}$

affected the microbial communities and their metabolism, making the comparison among experiments difficult. Nonetheless, any strategy to reduce net sulfide production needs to be robust enough to cope with potential changes in the input wastewater.

\subsection{Reduction of Net Sulfide Production Rate by Nitrate}

The decrease in $\mathrm{H}_{2} \mathrm{~S}$ concentration and the net sulfide production rate were always observed during the
Fig. 7 Relative abundance in percentage with respect to total bacteria of the different bacterial groups analyzed $72 \mathrm{~h}$ after nitrate addition in the different experiments. SRB:

$D B B$ Desulfobulbus, DBM Desulfobacterium, DSB Desulfobacter, DCC Desulfococcus, Desulfonema, and Desulfosarcina, DSV Desulfovibrio and Desulfomicrobium. NR-SOB: SFM $S$. denitrificans, PCC P. denitrificans, $T H B$ T. denitrificans
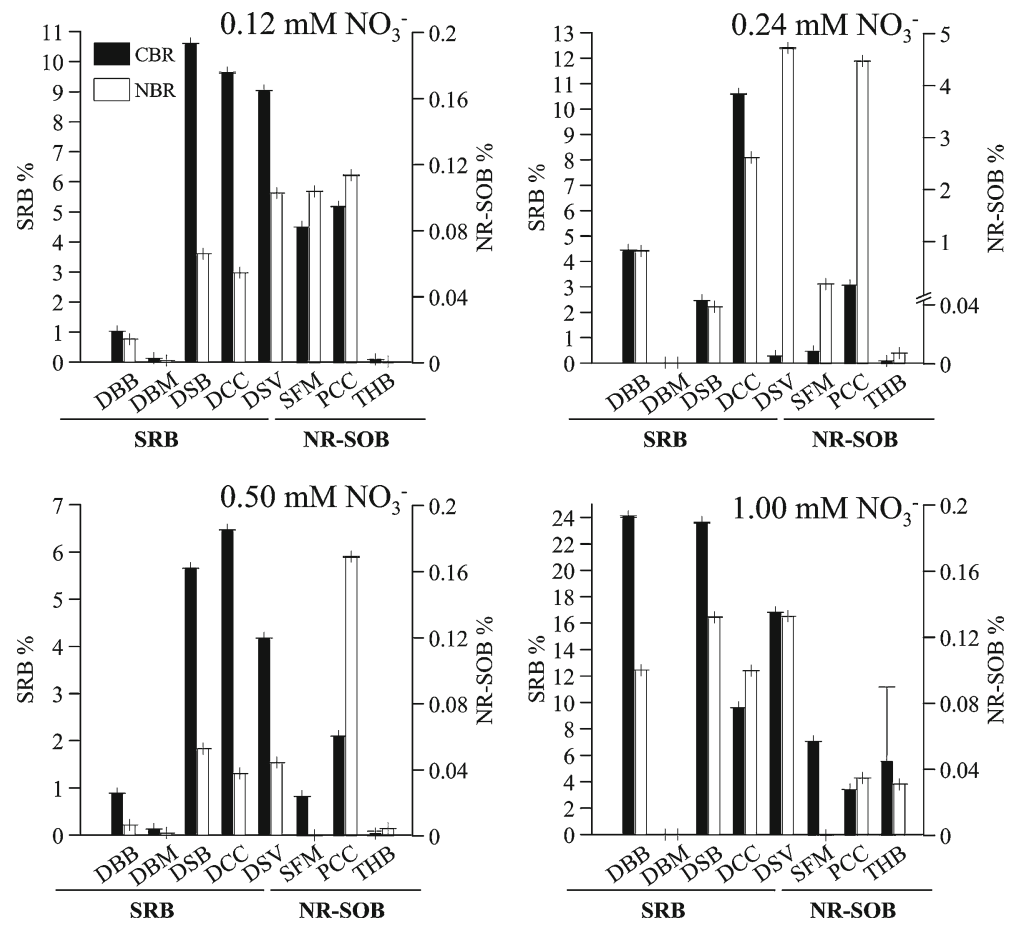
Table 5 Changes in the microbial community of NBR with respect to CBR $72 \mathrm{~h}$ after starting nitrate addition, determined by quantitative reverse transcription PCR

\begin{tabular}{|c|c|c|c|c|c|c|c|c|}
\hline \multirow[t]{2}{*}[\mathrm{NO}_{3}{}^{-}]{ added } & \multicolumn{3}{|c|}{ NR-SOB } & \multicolumn{5}{|l|}{ SRB } \\
\hline & SFM & PCC & THB & DBB & DBM & DSB & $\mathrm{DCC}$ & DSV \\
\hline $0.12 \mathrm{mM}$ & 1.26 & 1.20 & 0.40 & 0.75 & 0.44 & 0.34 & 0.31 & 0.62 \\
\hline $0.24 \mathrm{mM}$ & 21.52 & 27.83 & 3.55 & 0.99 & 0.94 & 0.90 & 0.76 & 45.57 \\
\hline $0.50 \mathrm{mM}$ & 7.35 & 2.80 & 3.12 & 0.24 & 0.33 & 0.32 & 0.20 & 0.37 \\
\hline $1.00 \mathrm{mM}$ & 1.20 & 1.25 & 0.69 & 0.52 & 1.55 & 0.70 & 1.29 & 0.98 \\
\hline
\end{tabular}

NBR/CBR ratios for the major SRB and NR-SOB groups

NR-SOB: SFM S. denitrificans, PCC P. denitrificans, THB T. denitrificans. SRB: DBB Desulfobulbus, DBM Desulfobacterium, DSB Desulfobacter, DCC Desulfococcus, Desulfonema, and Desulfosarcina, DSV Desulfovibrio and Desulfomicrobium

experiments and were dependent on the amount of nitrate added (Figs. 3 and 4). However, taking into account that the NR-SOB community was mainly located in biofilms (Garcia de Lomas et al. 2007), nitrate from the water phase might not reach the bottom of the biofilms, while SRB activity could persist using the sulfate regenerated within the biofilms by the activity of NR-SOB (Garcia de Lomas et al. 2007; Ito et al. 2002; Okabe et al. 2003), leading to the maintenance of a basal sulfide production, as suggested by the nonlinear decrease of the normalized sulfide concentration in NBR with the nitrate dose (Fig. 3).

The increase of SEE in relation to the amount of added nitrate presented a higher $K_{\mathrm{s}}\left(0.63 \mathrm{mM} \mathrm{NO}_{3}{ }^{-}\right)$ than those measured in semicontinuous master culture reactors (0.048-0.160 mM) (Oh et al. 2000). However, the bacterial biomass in those cultures consisted mainly of autotrophic denitrifying sulfur bacteria since they were fed with thiosulfate and nitrate without any organic $\mathrm{C}$ source and, therefore, different $K_{\mathrm{s}}$ value would be expected. The relatively high value of $K_{\mathrm{s}}$ measured in our experiments, compared with the basal nitrate concentration, suggests that the NR-SOB community in our experiments was severely limited by nitrate.

Atmospheric sulfide release was variable (Fig. 5), but its reduction or even elimination was clear after the addition of nitrate and it also depended on the concentration of nitrate. In our experimental system, $0.5 \mathrm{mM}$ $\mathrm{NO}_{3}{ }^{-}$was enough to suppress the release of sulfide to the atmosphere, but it was insufficient to fully eliminate $\mathrm{H}_{2} \mathrm{~S}$ in water, so it seems possible to reduce the dose of nitrate considerably if the technical target is only to avoid the release to the atmosphere.

\subsection{Reversibility of Nitrate Effect}

The reduction of net sulfide production by nitrate is reversible (Garcia de Lomas et al. 2007; Okabe et al. 2003). Previous experiments showed that the response of microbial community to the addition of nitrate occurred in 2-3 h (Garcia de Lomas et al. 2007; Mohanakrishnan et al. 2011) and that, once the nitrate dosage was suspended, sulfide concentration increased in a similar timescale (Garcia de Lomas et al. 2006, 2007). However, a continuous exposure to nitrate for 3 days was long enough to modify the microbial community, what is likely to increase both the capacity and the affinity of the system for nitrate. Therefore, this "activated" community could use more efficiently basal nitrate in the wastewater and reduce sulfide release. However, the recovery time was similar in every experiment (about $3 \mathrm{~h}$ ) independently of the nitrate concentration applied. These results suggest that strategies based on pulsed nitrate dosage (Gutierrez et al. 2010; Mohanakrishnan et al. 2009) could be in some systems ineffective for the reduction of sulfide production.

\subsection{Nitrogen, Sulfur, and Carbon Metabolism}

The net production rates measured here represent the steady-state mean net balance of different biotic (metabolic pathways) and abiotic processes. Therefore, interpretation based on stoichiometric principles (Gadekar et al. 2006; Cardoso et al. 2006) must be cautious.

The microbial communities of NBR and CBR were net consumers of nitrate with a very high demand. The immediate consumption of nitrate dosed to NBR indicates the existence of a native NR-SOB community, 
capable of quickly increasing its activity in the presence of added $\mathrm{NO}_{3}{ }^{-}$(Garcia de Lomas et al. 2007). This community seems to be strongly limited by nitrate, as suggested by the relatively high $K_{\mathrm{s}}$ compared with the mean nitrate concentration in the bioreactors and the fact that the mean net $\mathrm{NO}_{3}{ }^{-}$reduction rate was two orders of magnitude higher in NBR than in CBR. In our experimental conditions, the net $\mathrm{NO}_{3}{ }^{-}$reduction rate might account for autotrophic dissimilatory nitrate reduction (i.e., NR-SOB activity) and heterotrophic dissimilatory nitrate reduction that would compete with SRB for organic electron donors (Hubert and Voordouw 2007). Although we have no conclusive information on the importance of the latter, previous results using molecular techniques indicate an increase in the activity of NR-SOB, rather than inhibition of sulfate reduction activity (Garcia de Lomas et al. 2007; Mohanakrishnan et al. 2011). Therefore, and because we detected high activity of NR-SOB in the reactors supplemented with nitrate, we assume that, in the present experiment, all or most of the net $\mathrm{NO}_{3}{ }^{-}$reduction is the result of the activity of NR-SOB.

The significantly higher net rates of nitrite production and nitrite concentrations in NBR than in CBR (Tables 3 and 4, respectively) suggest an imbalance between the overall nitrate and nitrite reductase activities. The accumulation of nitrite is usually associated to the incomplete oxidation of $\mathrm{H}_{2} \mathrm{~S}$ to $\mathrm{S}^{0}$ instead of $\mathrm{SO}_{4}{ }^{2-}$ (Gadekar et al. 2006; Cardoso et al. 2006). Visual evidence of $S^{0}$ formation was found in the form of whitish layers in the biofilms (Moraes et al. 2011). Total inorganic nitrogen concentrations $\left(\mathrm{TIN}=\mathrm{NH}_{4}{ }^{+}+\mathrm{NO}_{3}{ }^{-}+\mathrm{NO}_{2}{ }^{-}\right)$during and after nitrate addition in NBR were not significantly different to those found in CBR (paired $t$ test, $p=0.804$; Table 4), then it seems that the chemolithotrophic reduction of nitrate by NR-SOB in our experimental system progress rather efficiently to a gaseous form of $\mathrm{N}$. This was partially confirmed by the observed increase of $\mathrm{N}_{2} \mathrm{O}$ in NBR during experiments at 0.12 and $0.24 \mathrm{mM}$ nitrate dosages (data not shown). Therefore, we can assume that the application of these amounts of nitrate is innocuous for the receiving waters, since it will not contribute to increase the anthropogenic input of $\mathrm{N}$ and it will not negatively affect the depuration process, as indicated by the lower net DOC production in NBR. However, the possible formation of $\mathrm{N}_{2} \mathrm{O}$ or $\mathrm{N}_{2}$ as end products has strong environmental implications for atmospheric pollution due to the strong global warming potential of $\mathrm{N}_{2} \mathrm{O}$ (Linak and Kramlich 1998). Further research is needed to understand the microbial metabolic pathways and the environmental conditions that favor the formation of $\mathrm{N}_{2}$ with respect to $\mathrm{N}_{2} \mathrm{O}$ as final product.

Net sulfide production rate can be estimated by net sulfate reduction rate, calculated as the consumption of sulfate in the NBR and CBR (Table 3). The net sulfate reduction rate was $27.04 \mathrm{mmol} \mathrm{SO}_{4}{ }^{2-} \mathrm{m}^{-2} \mathrm{~h}^{-1}$, but $3.86 \mathrm{mmol} \mathrm{H}_{2} \mathrm{~S} \mathrm{~m}^{-2} \mathrm{~h}^{-1}$, accumulated in the medium. Therefore, the difference was being oxidized by NRSOB activity $\left(23.18 \mathrm{mmol} \mathrm{H}_{2} \mathrm{~S} \mathrm{~m}^{-2} \mathrm{~h}^{-1}\right)$. Since nitrate consumption rate (NR-SOB activity) was $22.53 \mathrm{mmol}$ $\mathrm{NO}_{3}{ }^{-} \mathrm{m}^{-2} \mathrm{~h}^{-1}$, the stoichiometric ratio between $\mathrm{HS}^{-}$ and $\mathrm{NO}_{3}{ }^{-}$in NBR was 1.03. Gadekar et al. (2006) proposed a stoichiometric ratio of 1 according to following reaction:

$\mathrm{HS}^{-}+\mathrm{NO}_{3}{ }^{-}+\mathrm{H}^{+} \rightarrow \mathrm{S}^{0}+\mathrm{NO}_{2}{ }^{-}+\mathrm{H}_{2} \mathrm{O}$

However, the net nitrite production rate was much lower than expected from the $\mathrm{NO}_{3}{ }^{-} / \mathrm{NO}_{2}{ }^{-}$stoichiometry of the previous reaction, indicating the production of a gaseous form of $\mathrm{N}$ (we confirmed the production of $\mathrm{N}_{2} \mathrm{O}$ in two experiments where we could measure it; results not shown). Further oxidation of elemental sulfur to sulfate by nitrate and nitrite have been observed when sulfide concentration is low, producing a gaseous form of N (Gadekar et al. 2006).

\subsection{Microbial Community}

Wastewater biofilms are complex and highly diverse microbial communities with a high degree of functional integration. Significant differences in the microbial community between both reactors were detected after 3 days of nitrate dosage, in spite of the wide variability of physicochemical characteristics of the inflowing wastewater and the most likely different initial microbial communities in the successive experiments. These changes confirmed the importance of NR-SOB microorganisms in the control of net sulfide production rate by nitrate (Garcia de Lomas et al. 2006, 2007; Mohanakrishnan et al. 2009, 2011). We detected an increase in sequences closely related to $S$. denitrificans and P. denitrificans in NBR with respect to CBR in all the experiments. However, the magnitude of the increase was very different and apparently not related to the dose of nitrate. The maximum increase, one order of magnitude larger, was found with $0.24 \mathrm{mM}$ nitrate; however, we did not observe any remarkable difference in chemical 
variables $\left(\mathrm{H}_{2} \mathrm{~S}, \mathrm{NO}_{3}{ }^{-}, \mathrm{NO}_{2}{ }^{-}\right.$, etc. $)$that could explain it. Similarly, we detected both increases and decreases on the representation of $T$. denitrificans in the NR-SOB community depending on the experiment, but, again, these were not correlated with the metabolic response of the microbial community to nitrate. Nonetheless, we always observed a clear reduction of sulfide after the addition of nitrate, despite the differences observed in the changes in the microbial community between experiments. In addition, a significant linear correlation $\left(R^{2}=0.59, p=0.002\right)$ between denitrification and sulfide removal rates calculated from the bioreactors mass balance was observed.

In this study, we show the involvement of $P$. denitrificans as a potential major denitrifier and sulfur oxidizer in the removal of sulfide from wastewaters for the first time, while previous studies analyzed mainly $S$. denitrificans and T. denitrificans with differential participation of these two major groups. P. denitrificans is a high metabolically versatile bacterium presenting a great flexibility of electron donors and acceptors (Baker et al. 1998). This species is able to oxidize sulfide coupled to nitrate reduction in a similar net mechanism as described in the case of $S$. denitrificans (Garcia de Lomas et al. 2006). Besides, P. denitrificans opens a novel and interesting possibility to the engineering of nitrogen cycling in wastewaters, since it has also been described to be able to behave as a heterotrophic nitrifier oxidizing ammonia to nitrite and nitrate and subsequently perform denitrification. Moreover, $P$. denitrificans could foster the release of $\mathrm{N}_{2}$ from the ammonium produced by heterotrophic microorganisms during the reduction and utilization of nitrate.

Our results show a general decrease of SRB under nitrate dose. Similar to the NR-SOB community, we did not detect any relation between the decrease of activity of the different SRB taxonomic groups studied here and the nitrate dose. The syntrophic relationship between SRB and NR-SOB communities might be complex. Some genera of SRB could be well adapted to participate in syntrophy, for instance, being able to detoxify nitrite with nitrite reductase activity like Desulfovibrio (Greene et al. 2003), and some genera of SRB (Desulfovibrio, Desulfobulbus, and Desulfomonas) are even able to reduce nitrate as terminal electron acceptor (Ito et al. 2002). Nevertheless, although there was lower relative presence of major SRB group rRNA bands, the higher sulfate reduction rate in NBR indicates that some other SRB groups could take over and maintain high levels of sulfate reduction activity in the presence of an activated NRSOB community after nitrate addition.

Acknowledgments We acknowledge the support of the grants P06-RNM-01787, P11-RNM-7199, the PAI groups RNM-214 and BIO-288 from Consejería de Innovación, Ciencia y Empresa, Junta de Andalucía, Spain and CTM2009-10736 from the Ministerio de Innovación y Ciencia, Spain, which include cofinancing from FEDER funds. S. Papaspyrou was funded by a JAE-Doc fellowship (Programa JAE, JAE-Doc 109, Spanish National Research Council) and a Marie Curie ERG action (NITRICOS, 235005, European Union). We also want to acknowledge the personnel from Guadalete WWTP and AJEMSA for the technical help and providing us the physicochemical analysis of raw wastewater during 2008 and 2009 and E. Iglesias from Yara Iberian for providing nitrate.

\section{References}

Aelion, C. M., Rust, C. M., \& Flora, J. R. V. (2000). Control of pH during denitrification in subsurface sediment microcosms using encapsulated phosphate buffer. Water Research, 34(5), 1447-1454.

Allen, L. A., Brooks, E., \& Williams, I. L. (1949). Effect of treatment at the sewage works on the numbers and types of bacteria in sewage. Journal of Hygiene (Lond), 47(3), 303319.

American Public Health Association, American Water Works Association, \& Water Environment Federation. (2005). Standard methods for the examination of water and wastewater (21st ed.). Washington, DC: American Public Health Association.

Baker, S. C., Ferguson, S. J., Ludwig, B., Page, M. D., Richter, O. M., \& van Spanning, R. J. (1998). Molecular genetics of the genus Paracoccus: Metabolically versatile bacteria with bioenergetic flexibility. Microbiology and Molecular Biology Reviews, 62(4), 1046-1078.

Beech, I. B., \& Sunner, J. (2004). Biocorrosion: Towards understanding interactions between biofilms and metals. Current Opinion in Biotechnology, 15(3), 181-186. doi:10.1016/j. copbio.2004.05.001.

Boon, A. G. (1995). Septicity in sewers - Causes, consequences and containment. Water Science and Technology, 31(7), 237-253.

Cardoso, R. B., Sierra-Alvarez, R., Rowlette, P., Flores, E. R., Gomez, J., \& Field, J. A. (2006). Sulfide oxidation under chemolithoautotrophic denitrifying conditions. Biotechnology and Bioengineering, 95(6), 1148-1157. doi:10.1002/bit.21084.

Cord-Ruwisch, R. (1985). A quick method for the determination of dissolved and precipitated sulfides in cultures of sulfate reducing bacteria. Journal of Microbiological Methods, 4(1), 33-36. doi:10.1016/0167-7012(85)90005-3.

Daly, K., Sharp, R. J., \& McCarthy, A. J. (2000). Development of oligonucleotide probes and PCR primers for detecting phylogenetic subgroups of sulfate-reducing bacteria. Microbiology, 146(Pt 7), 1693-1705. 
Eckford, R. E., \& Fedorak, P. M. (2004). Using nitrate to control microbially-produced hydrogen sulfide in oil field waters. Petroleum Biotechnology: Developments and Perspectives, 151, 307-340.

Gadekar, S., Nemati, M., \& Hill, G. A. (2006). Batch and continuous biooxidation of sulphide by Thiomicrospira sp. CVO: Reaction kinetics and stoichiometry. Water Research, 40(12), 2436-2446. doi:10.1016/j.watres.2006. 04.007.

Garcia de Lomas, J., Corzo, A., Carmen Portillo, M., Gonzalez, J. M., Andrades, J. A., Saiz-Jimenez, C., et al. (2007). Nitrate stimulation of indigenous nitrate-reducing, sulfideoxidising bacterial community in wastewater anaerobic biofilms. Water Research, 41(14), 3121-3131. doi:10. 1016/j.watres.2007.04.004.

Garcia de Lomas, J., Corzo, A., Gonzalez, J. M., Andrades, J. A., Iglesias, E., \& Montero, M. J. (2006). Nitrate promotes biological oxidation of sulfide in wastewaters: Experiment at plant-scale. Biotechnology and Bioengineering, 93(4), 801-811. doi:10.1002/bit.20768.

Gevertz, D., Telang, A. J., Voordouw, G., \& Jenneman, G. E. (2000). Isolation and characterization of strains CVO and FWKO B, two novel nitrate-reducing, sulfide-oxidizing bacteria isolated from oil field brine. Applied and Environmental Microbiology, 66(6), 2491-2501.

Grasshoff, K., Ehrhardt, M., Kremling, K., \& Almgren, T. (1983). Methods of seawater analysis. Weinheim: Verlag Chemie (2nd. revised and extended edition).

Greene, E. A., Hubert, C., Nemati, M., Jenneman, G. E., \& Voordouw, G. (2003). Nitrite reductase activity of sulphatereducing bacteria prevents their inhibition by nitrate-reducing, sulphide-oxidizing bacteria. Environmental Microbiology, 5(7), 607-617.

Gutierrez, O., Sutherland-Stacey, L., \& Yuan, Z. (2010). Simultaneous online measurement of sulfide and nitrate in sewers for nitrate dosage optimisation. Water Science and Technology, 61(3), 651-658. doi:10.2166/wst.2010.901.

Hubert, C., \& Voordouw, G. (2007). Oil field souring control by nitrate-reducing Sulfurospirillum spp. that outcompete sulfate-reducing bacteria for organic electron donors. Applied and Environmental Microbiology, 73(8), 26442652. doi:10.1128/AEM.02332-06.

Hubert, C., Voordouw, G., \& Mayer, B. (2009). Elucidating microbial processes in nitrate- and sulfate-reducing systems using sulfur and oxygen isotope ratios: The example of oil reservoir souring control. Geochimica Et Cosmochimica Acta, 73(13), 3864-3879. doi:10.1016/j.gca.2009.03.025.

Ito, T., Nielsen, J. L., Okabe, S., Watanabe, Y., \& Nielsen, P. H. (2002). Phylogenetic identification and substrate uptake patterns of sulfate-reducing bacteria inhabiting an oxicanoxic sewer biofilm determined by combining microautoradiography and fluorescent in situ hybridization. Applied and Environmental Microbiology, 68(1), 356-364.

Jenneman, G. E., McInerney, M. J., \& Knapp, R. M. (1986). Effect of nitrate on biogenic sulfide production. Applied and Environmental Microbiology, 51(6), 1205-1211.

Jiang, G., Sharma, K. R., Guisasola, A., Keller, J., \& Yuan, Z. (2009). Sulfur transformation in rising main sewers receiving nitrate dosage. Water Research, 43(17), 44304440. doi:10.1016/j.watres.2009.07.001.

Leitao, R. C., van Haandel, A. C., Zeeman, G., \& Lettinga, G. (2006). The effects of operational and environmental variations on anaerobic wastewater treatment systems: A review. Bioresource Technology, 97(9), 1105-1118. doi:10. 1016/j.biortech.2004.12.007.

Linak, W. P., \& Kramlich, J. C. (1998). A review of nitrous oxide behavior in the atmosphere, and in combustion and industrial systems. In T. Schneider (Ed.), Studies in environmental science (vol. 72, pp. 265-313). Amsterdam: Elsevier.

Mohanakrishnan, J., Gutierrez, O., Sharma, K. R., Guisasola, A., Werner, U., Meyer, R. L., et al. (2009). Impact of nitrate addition on biofilm properties and activities in rising main sewers. Water Research, 43(17), 4225-4237. doi:10.1016/j. watres.2009.06.021.

Mohanakrishnan, J., Kofoed, M. V., Barr, J., Yuan, Z., Schramm, A., \& Meyer, R. L. (2011). Dynamic microbial response of sulfidogenic wastewater biofilm to nitrate. Applied Microbiology and Biotechnology, 91(6), 1647-1657. doi:10.1007/s00253-011-3330-3.

Molin, S., \& Givskov, M. (1999). Application of molecular tools for in situ monitoring of bacterial growth activity. Environmental Microbiology, 1(5), 383-391.

Moraes, B. S., Souza, T. S., \& Foresti, E. (2011). Characterization and kinetics of sulfide-oxidizing autotrophic denitrification in batch reactors containing suspended and immobilized cells. Water Science and Technology, 64(3), 731-738.

Neefs, J. M., Van de Peer, Y., Hendriks, L., De Wachter, R. (1990). Compilation of small ribosomal subunit RNA sequences. Nucleic Acids Research, 18 Suppl, 2237-2317.

Nemati, M., Jenneman, G. E., \& Voordouw, G. (2001a). Impact of nitrate-mediated microbial control of souring in oil reservoirs on the extent of corrosion. Biotechnology Progress, 17(5), 852-859. doi:10.1021/bp010084v.

Nemati, M., Mazutinec, T. J., Jenneman, G. E., \& Voordouw, G. (2001b). Control of biogenic H(2)S production with nitrite and molybdate. Journal of Industrial Microbiology and Biotechnology, 26(6), 350-355.

Nielsen, P. H. (1987). Biofilm dynamics and kinetics during high-rate sulfate reduction under anaerobic conditions. Applied and Environmental Microbiology, 53(1), 27-32.

Oh, S. E., Kim, K. S., Choi, H. C., Cho, J., \& Kim, I. S. (2000). Kinetics and physiological characteristics of autotrophic denitrification by denitrifying sulfur bacteria. Water Science and Technology, 42(3-4), 59-68.

Okabe, S., Santegoeds, C. M., \& De Beer, D. (2003). Effect of nitrite and nitrate on in situ sulfide production in an activated sludge immobilized agar gel film as determined by use of microelectrodes. Biotechnology and Bioengineering, 81(5), 570-577. doi:10.1002/bit.10495.

Poduska, R. A., \& Anderson, B. D. (1981). Successful storage lagoon odor control. Journal Water Pollution Control Federation, 53(3), 299-310.

Roberts, D. J., Nica, D., Davis, J. L., Kirby, L., \& Zuo, G. (2000). Isolation and characterization of microorganisms involved in the biodeterioration of concrete in sewers. International Biodeterioration \& Biodegradation, 46(1), 61-68. 
Rutledge, R. G. (2004). Sigmoidal curve-fitting redefines quantitative real-time PCR with the prospective of developing automated high-throughput applications. Nucleic Acids Research, 32(22), e178. doi:10.1093/nar/gnh177.

Snaidr, J., Amann, R., Huber, I., Ludwig, W., Schleifer, K. H. (1997). Phylogenetic analysis and in situ identification of bacteria in activated sludge. Appl Environ Microbiol, 63(7), 2884-2896.

Tang, K., Baskaran, V., \& Nemati, M. (2009). Bacteria of the sulphur cycle: An overview of microbiology, biokinetics and their role in petroleum and mining industries. Biochemical Engineering Journal, 44(1), 73-94. doi:10.1016/j.bej.2008.12.011.

Vaiopoulou, E., Melidis, P., \& Aivasidis, A. (2005). Sulfide removal in wastewater from petrochemical industries by autotrophic denitrification. Water Research, 39(17), 41014109. doi:10.1016/j.watres.2005.07.022.
Van Rijn, J., Tal, Y., \& Schreier, H. J. (2006). Denitrification in recirculating systems: Theory and applications. Aquacultural Engineering, 34(3), 364-376. doi:10.1016/j.aquaeng.2005. 04.004.

Voordouw, J. K., \& Voordouw, G. (1998). Deletion of the rbo gene increases the oxygen sensitivity of the sulfate-reducing bacterium Desulfovibrio vulgaris Hildenborough. Applied and Environmental Microbiology, 64(8), 2882-2887.

Yuan, Z. G., Jiang, G. M., Gutierrez, O., \& Sharma, K. R. (2010). Effects of nitrite concentration and exposure time on sulfide and methane production in sewer systems. Water Research, 44(14), 4241-4251. doi:10.1016/j.watres.2010.05.030.

Zhang, J. Z., \& Fischer, C. J. (2006). A simplified resorcinol method for direct spectrophotometric determination of nitrate in seawater. Marine Chemistry, 99(1-4), 220-226. doi:10.1016/j.marchem.2005.09.008. 